Int. J. Odontostomat., 10(1):17-22, 2016.

\title{
The Imaging Appearance of Sinus Mycetoma: A Case Series
}

\author{
El Aspecto Imagenológico del Micetoma Sinusal: Serie de Casos \\ Ilich Vargas ${ }^{*, * *}$; Felipe Sáez ${ }^{*, * *}$; Christian Pedemonte*; Hernan Pérez* \& Marco Canales*
}

VARGAS, I.; SÁEZ, F.; PEDEMONTE, C.; PÉREZ, H. \& CANALES, M. The imaging appearance of sinus mycetoma: A case series. Int. J. Odontostomat., 10(1):17-22, 2016.

ABSTRACT: Sinus mycetoma is a dense accumulation of hyphae that form a rounded mass within the mucosal confines of a paranasal sinus. The aim of this study was to present a case series of three patients with maxillary sinus mycetoma and to describe their radiographic presentations. Three cases are presented. The first two, a 44-year-old woman and an 88 year-old man, both diabetics, were referred to maxillofacial treatment by other specialties. They both had a bad odor of unknown origin on the facial level and their respective computerized tomographies revealed a unilateral opacification of the maxillary sinus with a region of greater radio-opacity. The third case is a 31-year-old woman with a history of a severe facial trauma who had undergone surgery and for whom orthognathic surgery had been planned to correct side effects. In addition to the orthognathic surgery, the removal of the lesion that appeared opacified in the pre-surgery scan was planned. She showed opacification of the maxillary sinus and during the intraoperative stage, tissue of a whitish-gray appearance was detected on the maxillary sinus. The lesion was completely removed and the result of the histopathological study was sinus mycetoma. The patients evolved favorably and the symptomatology disappeared completely. The growing occurrence of mycetoma and the lack of information on it make publicizing this pathology fundamental so it can be considered as a differential imaging, clinical, and pathological diagnosis and in that way receive adequate and opportune treatment.

KEY WORDS: mycetoma, maxillary sinus, aspergillus, mucor.

\section{INTRODUCTION}

The growing number of mycotic infections in nasal and paranasal cavities is mostly due to the fact that the diagnostic methods currently exist, especially when it comes to new diagnostic techniques using imagery, such as computerized tomography and magnetic resonance, but also because the population increasingly lives in conditions that favor the spread of fungi, such as longer life expectancy and general chronic diseases that have a major impact on the immune system, such as diabetes mellitus, or which require the prolonged use of medication to be treated, such as antibiotics and corticoids, radiotherapy, immunosuppressive treatments, and diseases that depress the immune system (De Foer et al., 1990; Costa et al., 2007)

The paranasal sinuses are the ideal environments for the development of fungi, with a lack of light but with a wide range of nutrients available (Mensi et al., 2004; Matjaz et al., 2004). Sinus mycetoma is an accumulation of hyphae that form a rounded mass known as a fungal ball in the international literature and in the majority of cases it involves colonization by Aspergillus spp. (Asp) and usually affects the maxillary and sphenoidal sinuses (Ferguson, 2000; Pagella et al., 2007). This so-called fungal ball causes bone necrosis by pressuring the surrounding bone tissue, just like allergic sinusitis (Lenglinger et al., 1996). On the other hand, it has also been discovered in apparently healthy patients, which suggests that the local factors involved also play an important role (deShazo et al., 1997). Regarding the classification of fungal rhinosinusitis, it is essentially divided into its invasive and noninvasive forms (Falworth \& Herold, 1996; Krenmair \& Lenglinger, 1995) (see Table I).

\footnotetext{
* Department of Maxillofacial Surgery. Hospital Clínico Mutual de Seguridad C.Ch.C., Santiago, Chile.

" Department of Maxillofacial Surgery. Hospital de Carabineros de Chile, Santiago, Chile.
} 
Table I. Classification of types of fungal Sinusitis. Adapted from DeShazo et al. (N Engl J Med 1997; 337:254-9).

\begin{tabular}{ll}
\hline Noninvasive & Invasive \\
\hline Fungal ball (sinus mycetoma) & Acutely necrotizing fungal rhinosinusitis \\
Allergic fungal rhinosinusitis & Chronic invasive fungal minosinusitis \\
& Invasive granulomatose minosinusitis \\
\hline
\end{tabular}

The different histopathological variants will present different radiographic traits. If the presence of a mass with radiodense focuses associated with a sinus occupation is detected (homogeneous opacification), it will strongly suggest noninvasive mycetoma. Colonization of the sinus with bone destruction will be characteristic of invasive forms. The final treatment will depend on whether the fungal sinusitis is invasive or not. In invasive cases, high doses of intravenous antifungals and, when necessary, radical surgery will be used, while in noninvasive cases the mass of hyphae will be removed, preferably through rhino-sinus endoscopic surgery (Callejas \& Douglas, 2013).

The most common symptoms are: face pain, purulent nasal discharges, a fetid smell perception and posterior nasal discharge. However, on occasions this lesion is found as a coincidental radiological discovery in asymptomatic patients (Costa et al.; Matjaz et al.; Koop et al., 1985).

\section{CASE REPORTS}

Case 1. A female patient, 44 years of age, with Type 2 Diabetes Mellitus treated with $850 \mathrm{mg}$ of Metformin per day, who was referred from otolaryngology to the Maxillofacial Surgery Service of the Hospital $N^{\circ} 1$ after a foreign body was found in her left maxillary sinus. The patient initially consulted with the otolaryngologist after detecting a persistent bad smell for three months. In addition, she noted heavy flows of nasal secretions in her left nostril, which were even somewhat scabby, though no pain was associated with it at any time.

Upon physical examination she presented normal facial symmetry without any associated deformity and with an obstructed left nostril with brown secretions, an absence of adenopathy, and with nothing special detected in the intraoral exam. A blood panel was ordered, in which all values were normal, as well as a Computerized Tomography (CT) of the craniofacial area and it revealed a partial opacification of the left maxillary sinus with an inferiorly located hyper-dense concretion in relation to a healthy tooth (Fig. 1). The patient underwent an excisional biopsy using the Caldwell Luc technique. Upon lifting the cover the inflamed mucus membrane was found covered in an amorphous greenish-brown mass. The mass was removed with profuse cleaning, preserving the mucus membrane of the sinus in a large part of the sinus. The decision was made not to replace the cover of bone tissue due to the compromised nature of its bone content. The histopathological report states: necrotic material and abundant Mucor and Aspergillus type fungal colonies (Fig. 2), leading to a diagnosis of sinus mycetoma. The

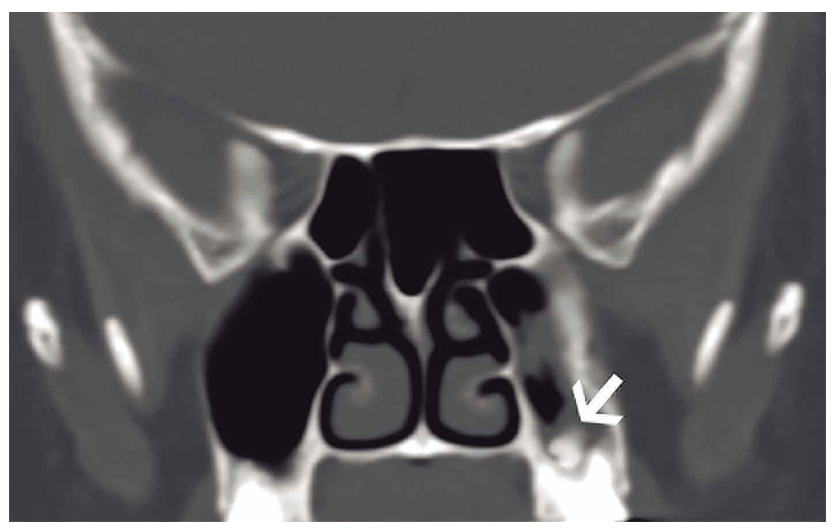

Fig. 1. Craniofacial non-contrast CT, Case 1. Coronal crosssection. Partial opacification of the left maxillary sinus. Note the inferiorly located (arrow) hyper-dense concretion in relation to a healthy tooth.

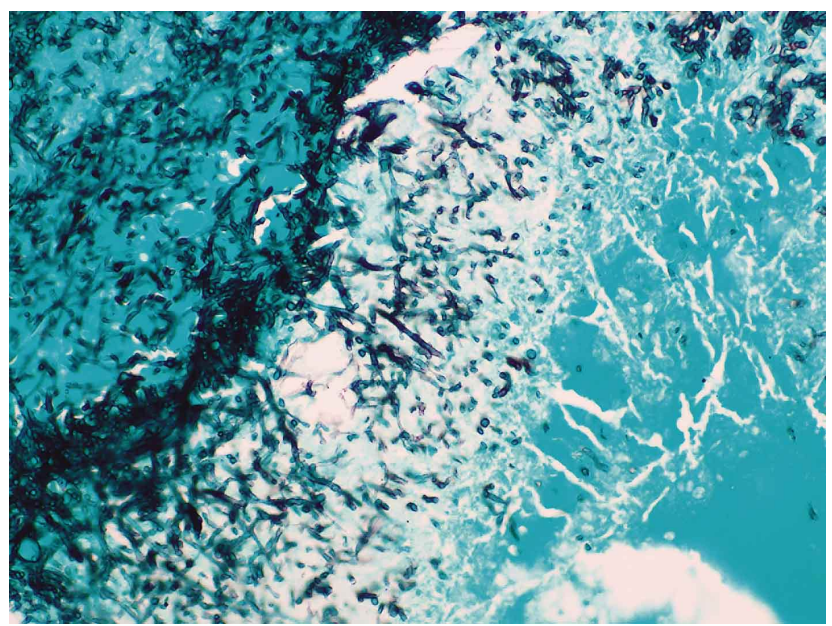

Fig. 2. Histological cross-section, Case 1. Grocott Stain to visualize fungal hyphae. 200x. 
patient evolved positively, the associated symptomatology disappeared and she was referred to infectious disease specialists. The control CT indicated an acute inflammatory pathology of the sinus of mild magnitude compromising the left maxillary sinus.

Case 2. A male patient, 88 years of age, who suffered mild encephalo-cranial traumatism in a car accident. A CT study was ordered and it revealed complete opacification of the right maxillary sinus with a region of greater hyper-density at its center, leading the patient

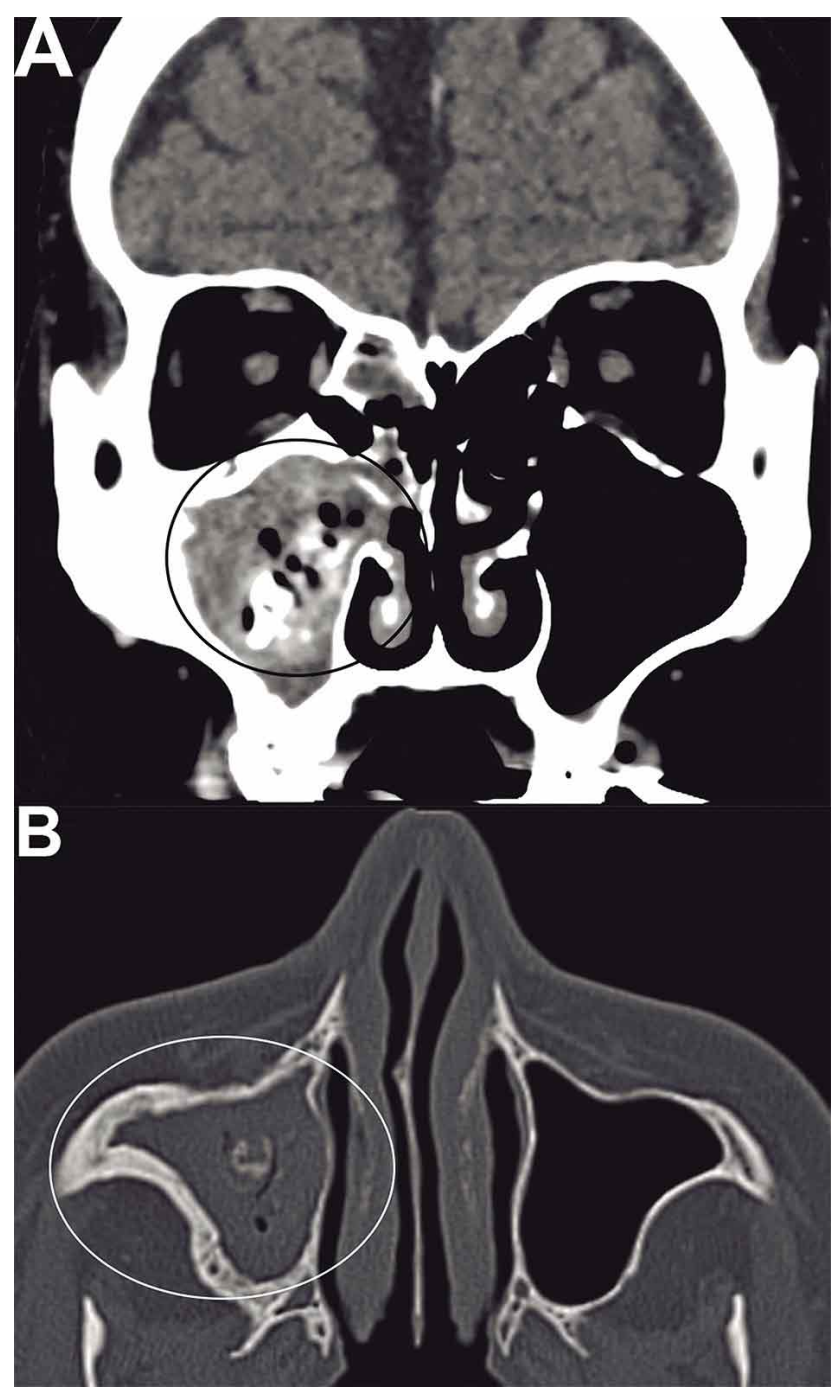

Fig. 3. A) Craniofacial non-contrast CT soft tissue window, Case 2. Coronal cross-section. Opacity of the right maxillary sinus can be observed, with a region of greater hyperdensity at its center. Note the hereogenous opacities which is characteristic of this condition. Additionally, note the extension in the ethmoid sinus. B) Axial cross-section, bone window. The mycetoma fills all of the maxillary sinus. Hyperdense body in the middle. to be referred to Maxillofacial Surgery Service of the Hospital $N^{\circ} 1$ (Fig. 3A and 3B). Regarding his morbidity indicators, he had arterial hypertension that was treated with atenolol and Type 2 Diabetes Mellitus being treated with metformin.

The only symptom that the patient presented prior to the radiographic discovery was a recurring bad odor whose origin he was unable to detect and which others also perceived. He was subjected to an excisional biopsy using the Caldwell Luc technique. The surgery revealed a mass of whitish-green color with a soft consistency and which disintegrated upon handling, without containing any hard elements inside (Fig. 4).

The histopathological diagnosis describes it as a sample of fragments of respiratory mucus, fragments of compact vital bone and structures formed by cellular detritus and devitalized mycotic elements. It recognizes multiple fragmented hyphae corresponding to Aspergillus spp, without these elements invading tissue

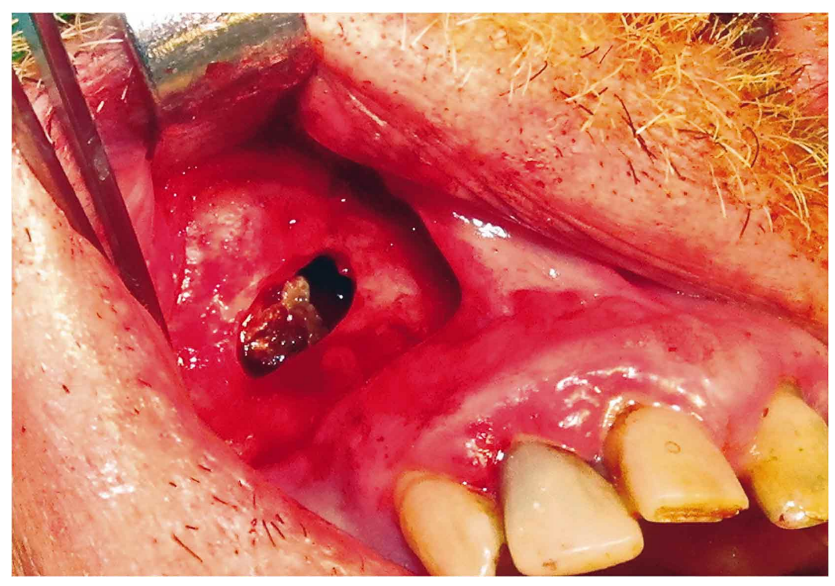

Fig. 4. Clinical image of the lesion, Case 2. Mass of whitishgreen color with a soft consistency that disintegrates upon handling.

in the sample analyzed. The final diagnosis concluded chronic sinusitis and mycetoma. The patient evolved favorably and the preoperative symptomatology disappeared completely.

Case 3. The third case is that of a 31-year-old woman who arrived at the maxillofacial surgery service of the Hospital $N^{\circ} 2$, with a history of operations for a hip fracture and a severe facial trauma after she was hit by a tractor, which kept her in the Intensive Care Unit (ICU) for over two months as she underwent treatment with corticoids and antibiotics (Fig. 5A). One year later, orthognathic surgery was planned to correct aftereffects and the CT revealed an opacification of the 


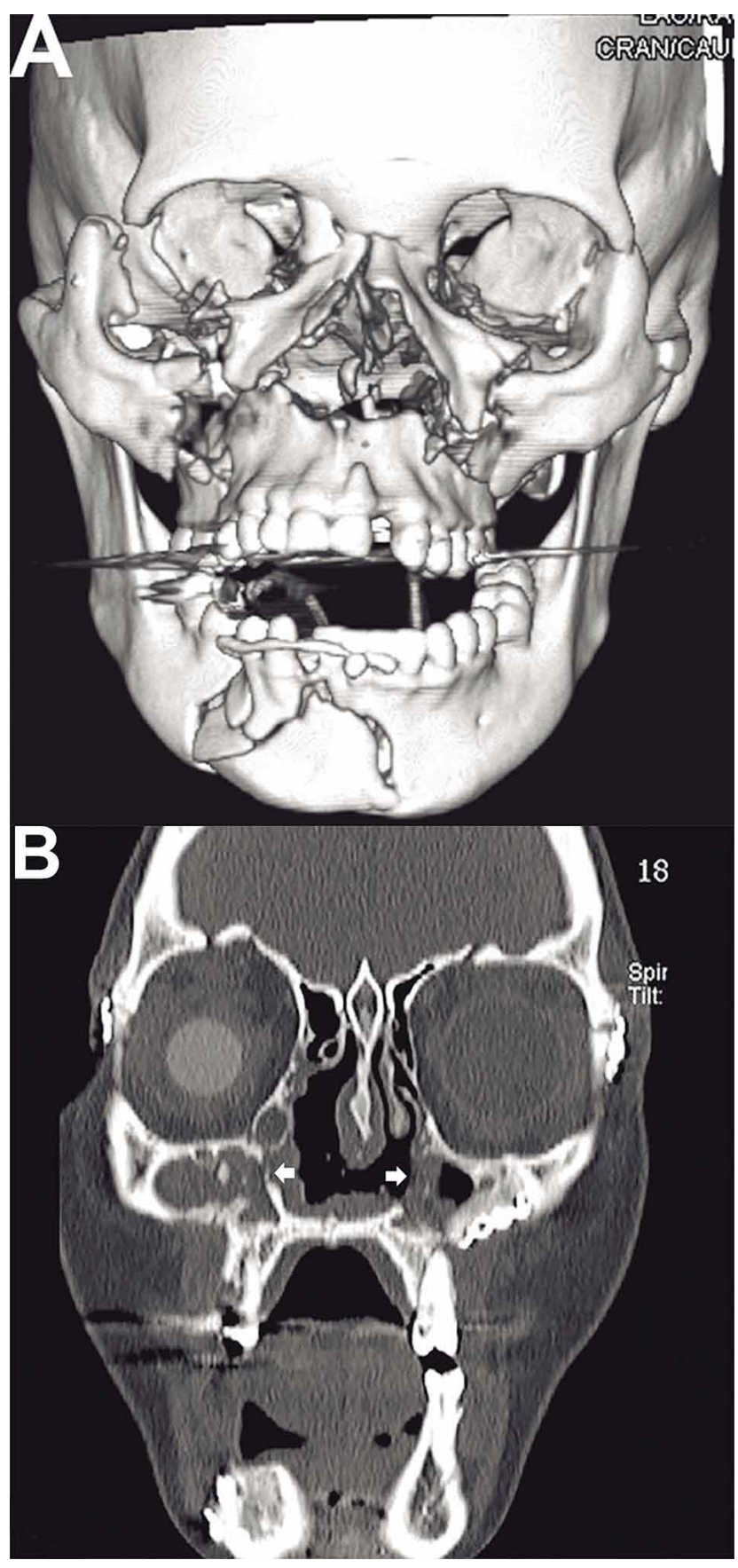

Fig. 5. A) Craniofacial initial CT, Case 3. 3D reconstruction. Panfacial fracture. Bilateral compromise of the orbitozygomatic complex, NOE, and orbital roof. Severe bilateral comminution of the anterior maxillary sinus wall is observed. In addition, fracture of paramedian and right mandibular body. B) Coronal cross-section, one year later with a new CT to plan orthognathic surgery to correct aftereffects and it revealed an opacification of the maxillary sinus with communication between both maxillary sinuses (arrows) and a total disruption of the anatomy of the area can be observed. In addition, the enucleation of the right eye revals an ocular prosthetic in its place. maxillary sinus with communication between both maxillary sinuses and a total disruption of the anatomy in the area (Fig. 5B). The intraoperative phase revealed whitish-gray tissue with a very bad smell on the right maxillary sinus, which was sent for biopsy. The histopathological report states that the sample corresponded to a necrotizing inflammatory process in bone tissue with a presence of bacterial and mycotic microbial flora compatible with mycetoma.

\section{DISCUSSION}

In general, aspergillosis was considered to be a fairly uncommon disease in the paranasal sinuses, a situation that has changed over recent years (Krenmair \& Lenglinger). It is not known whether this increase is due to increased access to diagnostic methods to detect it or whether the occurrence is related to an increased use of immunosuppressive agents for prolonged periods of time, such as the population's use of corticoids and antibiotics. The literature agrees that sinusitis of odontogenic origin would in the majority of cases affect just one paranasal sinus, while that of rhinogenic origin is often bilateral (Grosjean \& Weber, 2007; Dhong et al., 2000). The mycetoma in the clinical cases presented were unilateral and showed no signs or history that might link the appearance of the pathology with an odontogenic origin, like a endodontic treatment. What is conclusive is patients' systemic compromise, as the first two suffer from diabetes mellitus and the third was hospitalized in the ICU with corticoid and antibiotic treatment for a prolonged period of time, situations that would apparently favor the spread of fungal agents like Asp. It should be noted that in the first case Asp was not the only mycotic agent found, but that Mucor was, too. Several authors have reported similar cases, where it was thought that the fungal ball was secondary to Mucor (Dhong et al.; Henderson et al., 1988; Goodnight et al., 1993). However, the identification is questionable as a proper fungiculture for that species was never undertaken.

In the CT scan, the images of mycetoma have been described as "as a rim of soft tissue attenuation along the bone walls" (Callejas \& Douglas). They reveal heterogeneous opacities in the affected maxillary sinus, probably due to the accumulation of hemosiderin and metals like iron and manganese (essential for fungal amino acid metabolism). Small and very dense areas including metallic densities - are frequently observed in the CT. These areas of higher density can be attributed to local calcifications in the center of the mass of hyphae. 
However, these densities can also be observed in nonfungal maxillary sinusitis (Koop et al.). On the other hand, one must also consider that mycetoma can also appear without these radio-opacities. In such cases, the radioopaque concretion might have been lost via the natural orifice of the antrum, or the disease might have developed due to the inhalation of spores ("aerogenic theory") (Callejas \& Douglas). Though not indispensable, discoveries using nuclear resonance are more specific than those made with the CT. Hypodensity is usually observed in T1 and a signal void in T2 (due to the presence of calcium, air and ferromagnetic elements). Both series, T1 and T2, reveal peripheral enhancement (Koop et al.).

The ethiopathogenesis of sinus mycetoma caused by Asp is a subject of continual debate and today two lines are considered. One is "iatrogenic", the product of dental procedures (Mensi et al.). This theory suggests an initial colonization through oroantral communication, something that could be the product of a complicated tooth extraction, a dental implant, periodontal destruction or radicular perforation during an endodontic procedure (Lenglinger et al.). Several authors argue that endodontic sealants with a high zinc oxide content would act as a foreign body, altering the epithelial function, paralyzing the cilia and blocking mucociliary drainage, thus providing a hiding place for a fungal colonization that cannot be eliminated by the respiratory epithelium (De Foer et al.; Lenglinger et al.; deShazo et al.). The second ethiopathogenic theory "aerogenic" is contamination of the area due to the inhalation of numerous spores over a long period of time, as happens in Sudan, where Asp is endemic (Costa et al.; Lenglinger et al.). There is also a third mixed theory, in which the first instance is the inhalation of Asp spores, which after finding the ideal conditions spread through the paranasal sinuses (Costa et al.; Lenglinger et al.).

Another matter that stands out is the presence of radiodense focuses in the radiographic exams done in the cases analyzed, which initially led to the belief that a foreign body was lodged in the maxillary sinus, something that was ruled out after the excisional biopsy. Koop et al. report that 59 of 105 patients with mycetoma or aspergillosis in their paranasal sinuses, or $56 \%$ of the sample that presented radiodense focuses in their exams, did not have foreign bodies present (Grosjean \& Weber). The occurrence of these metallic-type opacities in the sinus is attributed to the presence of calcium sulfate or phosphate and heavy metal salts like iron, manganese and cadmium deposited in the necrotic areas of the mycetoma.
The common symptomatology in the first two cases analyzed was the bad odor, which was of unknown origin for both patients. This situation was produced by the formation of scabs firmly adhered to the nasal mucosa and formed by the atrophy of the epithelium, thus altering the secretion.

Another important point is the differential diagnosis, given that in the first case an otolaryngologist made the referral, with a possible diagnosis of a foreign body present, such as a tooth or an apex in the maxillary sinus, which highlights the need for all professionals to remain up-to-date with science so as to fine-tune diagnoses and to provide opportune and precise care that can often save lives. In these cases the mycetoma was noninvasive but the patients' evolution would have been totally different if it had been of the invasive type.

The deterioration caused by diseases that weaken the immune system, increases the fertile ground for the pathological spread of fungi like Aspergillus and Mucor. Their colonization of the paranasal sinuses can go unnoticed and their radiographic expression can mislead the treating professional. This type of report helps to improve knowledge of the signs and symptoms of this condition and is a reminder of their importance in a differential clinical diagnosis and proper treatment.

VARGAS, I.; SÁEZ, F.; PEDEMONTE, C.; PÉREZ, H. \& CANALES, M. El aspecto imagenológico del micetoma sinusal: Serie de casos. Int. J. Odontostomat., 10(1):1722, 2016.

RESUMEN: El micetoma sinusal es una patología de origen fúngico, que afecta a pacientes inmunocomprometidos, capaz de desorientar en su diagnóstico por su clínica y expresión imagenológica particular. El objetivo de este estudio es presentar una serie de tres casos con micetoma en el seno maxilar y describir su presentación imagenológica. Se presentan tres casos. Los dos primeros, una mujer de 44 años y un hombre de 88 años, ambos diabéticos y derivados a atención maxilofacial por otras especialidades. Coincidía un mal olor expelido de origen desconocido a nivel facial y en sus respectivas tomografías computarizadas se observó velamiento unilateral del seno maxilar con una zona de mayor hiperdensidad. El tercer caso corresponde a una mujer de 31 años con antecedente de trauma facial severo operado, a la cual se le planificó cirugía ortognática para corregir secuelas. En conjunto con la cirugía ortognática, se planificó la biopsia excisional de una lesión hiperdensa que se presentó en el escáner pre-quirúrgico; en el intraoperatorio se pesquisó tejido de aspecto blanquecino grisáceo en el seno maxilar. A todos los pacientes se les realizó la exéresis total de la lesión y el estudio histopatológico dio como resultado micetoma sinusal. Los 
pacientes evolucionaron favorablemente, desapareciendo por completo la sintomatología. La creciente incidencia del micetoma y el desconocimiento sobre el mismo hacen que sea fundamental la difusión de esta patología para ser considerada como diagnóstico diferencial clínico y patológico, y realizar así un tratamiento adecuado y oportuno.

PALABRAS CLAVE: micetoma, seno maxilar, Aspergillus, mucor.

\section{REFERENCES}

Callejas, C. A. \& Douglas, R. G. Fungal rhinosinusitis: what every allergist should know. Clin. Exp. Allergy, 43(8):83549, 2013.

Costa, F.; Polini, F.; Zerman, N.; Robiony, M.; Toro, C. \& Politi, M. Surgical treatment of Aspergillus mycetomas of the maxillary sinus: review of the literature. Oral Surg. Oral Med. Oral Pathol. Oral Radiol. Endod., 103(6):e23-9, 2007.

De Foer, C.; Fossion, E. \& Vaillant, J. M. Sinus aspergillosis. J. Craniomaxillofac. Surg., 18(1):33-40, 1990.

deShazo, R. D.; Chapin, K. \& Swain, R. E. Fungal sinusitis. N. Engl. J. Med., 337(4):254-9, 1997.

Dhong, H. J.; Jung, J. Y. \& Park, J. H. Diagnostic accuracy in sinus fungus balls: CT scan and operative findings. Am. J. Rhinol., 14(4):227-31, 2000.

Falworth, M. S. \& Herold, J. Aspergillosis of the paranasal sinuses. A case report and radiographic review. Oral Surg. Oral Med. Oral Pathol. Oral Radiol. Endod., 81(2):25560, 1996.

Ferguson, B. J. Fungus balls of the paranasal sinuses. Otolaryngol. Clin. North. Am., 33(2):389-98, 2000.

Goodnight, J.; Dulguerov, P. \& Abemayor, E. Calcified mucor fungus ball of the maxillary sinus. Am. J. Otolaryngol., 14(3):209-10, 1993.

Grosjean, P. \& Weber, R. Fungus balls of the paranasal sinuses: a review. Eur. Arch. Otorhinolaryngol., 264(5):461-70, 2007.

Henderson, L. T.; Robbins, K. T.; Weitzner, S.; Dyer, T. C. \& Jahrsdoerfer, R. A. Benign Mucor colonization (fungus ball) associated with chronic sinusitis. South Med. J., 81(7):846-50 1988.

Koop, W.; Fotter, R.; Steine, H.; Beaufort, F. \& Stammberger, $\mathrm{H}$. Aspergillosis of the paranasal sinuses. Radiology, 156(3):715-6, 1985.
Krennmair, G. \& Lenglinger, F. Maxillary sinus aspergillosis: diagnosis and differentiation of the pathogenesis based on computed tomography densitometry of sinus concretions. J. Oral Maxillofac. Surg., 53(6):657-63, 1995.

Lenglinger, F. X.; Krennmair, G.; Müller-Schelken, H. \& Artmann, W. Radiodense concretions in maxillary sinus aspergillosis: pathogenesis and the role of CT densitometry. Eur. Radiol., 6(3):375-9, 1996.

Matjaz, R.; Jernej, P. \& Mirela, K. R. Sinus maxillaris mycetoma of odontogenic origin: case report. Braz. Dent. J., 15(3):248-50, 2004.

Mensi, M.; Salgarello, S.; Pinsi, G. \& Piccioni, M. Mycetoma of the maxillary sinus: endodontic and microbiological correlations. Oral Surg. Oral Med. Oral Pathol. Oral Radiol. Endod., 98(1):119-23, 2004.

Pagella, F.; Matti, E.; De Bernardi, F.; Semino, L.; Cavanna, C.; Marone, P.; Farina, C. \& Castelnuovo, P. Paranasal sinus fungus ball: diagnosis and management. Mycoses, 50(6):451-6, 2007.

Correspondence to:

Felipe Sáez Salas

Department of Maxillofacial Surgery

Hospital Clínico Mutual de Seguridad C.Ch.C.

Av. Libertador Bernardo O'Higgins 4848

Santiago

CHILE

Email: fsaezsalas@gmail.com ilich.vargas@gmail.com

Received: 20-08-2014

Accepted: 27-10-2015 